\title{
The Assessment of the Suitability af Lemon Balm and Alder Buckthorn Wastes for the Biogas Production
}

\author{
Robert Czubaszek ${ }^{1}$ \\ 1 Department of Agri-Food Engineering and Environmental Management, Faculty of Civil and Environmental \\ Engineering, Białystok University of Technology, ul. Wiejska 45A, 15-351 Białystok, Poland \\ e-mail: r.czubaszek@pb.edu.pl
}

\begin{abstract}
The purpose of the study was to determine the suitability of wastes from herbal industry for the biogas production. The wastes of lemon balm (Melissa officinalis L.) and alder buckthorn (Frangula alnus Mill.) were used for the biomethane potential test (BMP). The following properties were determined in the tested material: total solids content (TS), volatile solids content (VS), total Kjeldahl nitrogen content (TKN), total organic carbon content (TOC), total phosphorus content $(\mathrm{P})$ and total potassium content $(\mathrm{K})$. The biogas yield was monitored on the basis of the liquid displacement method. The examined wastes differed in terms of the basic properties affecting the biogas production. Alder buckthorn contained more VS, TKN and TOC, while lemon balm had a narrower C/N ratio and higher $\mathrm{P}$ and $\mathrm{K}$ content. The tested wastes were also different in terms of the biogas production kinetics. In the case of lemon balm, the highest production was observed at the beginning of the experiment, while the anaerobic digestion of alder buckthorn waste was only noticeable in the third week of the experiment. This delay caused higher cumulative methane yield of lemon balm waste by about $60 \%$ than that of alder buckthorn. Despite those differences, the wastes from both plants were suitable for biogas production, mainly as co-substrates. Co-digestion resolves the problem of utilizing such wastes and decreases the demand for energy crops such as maize which should be used as fodder and food in the first place. In addition, clear differences in the kinetics of anaerobic digestion may cause that a simultaneous use of both tested wastes will ensure continuous biogas production at a relatively high level.
\end{abstract}

Keywords: biogas, lemon balm (Melissa officinalis), alder buckthorn (Frangula alnus)

\section{INTRODUCTION}

Biogas is one of the most developing and still promising renewable energy sources. The biogas plants are not only suppliers of biogas used for energy production but also generate digestate, which can and should be used as a valuable organic fertilizer. The digestate application has a positive impact on the basic properties of soils and supplies them in $\mathrm{N}$, mainly in the ammonium form, which is rapidly transformed to nitrates [Wysocka-Czubaszek 2019]. Digestate can be also a source of greenhouse gases. However, when appropriately used, it has little effect on the overall GHG emissions from agriculture [Czubaszek, Wysocka-Czubaszek 2018].

Biogas can be produced from various organic substances. The research on the specific biogas yield (SBY) included agricultural residues, animal waste (e.g., animal manure, animal slurry), sewage sludge, landfill and food waste, industrial waste, aquatic biomass, energy crops (e.g., maize silage, grass silage) and green waste. The most popular substrate used in commercial biogas plants is maize silage; however, due to the growing prices of this raw material and finite arable land area, it is necessary to search for the products that could reduce the demand for substrates, which can and should be primarily used for the nutritional purposes. Various types of post-production waste from industries processing plant materials can be a very good alternative to maize silage. Considering the fact that many organic industrial wastes have the methane potential of up to $500 \mathrm{~m}^{3} \mathrm{t}^{-1}$, these raw materials are very attractive substrates for biogas plants [Angelidaki, 
Ellegaard 2003]. The use of such substrate makes the biogas installation a pro-ecological source of energy that improves the quality of the environment and can therefore be considered as an integral part of environmental protection [Teleszewski, Żukowski 2018]. The research on the biogas potential of such underestimated substrates may reveal new energy source and solve utilization problem of these wastes.

The herbal products manufacturing is an example of the industry that has recently been developing in Poland. Herb plants, due to their aromatic properties, are widely used in the pharmaceutical, cosmetics, food and agriculture industries [Newerli-Guz 2016]. Although herbs and spices occupy only $\sim 0.3 \%$ of the total sown area in Poland, in recent years there has been a clear increase in farmers' interest in this type of crop. The sown area of herbs and spices in Poland in 2017 amounted to 30,564 ha, while the harvest exceeded 440,000 dt [Statistics Poland 2018]. Compared to the previous year, this represents an increase of $46 \%$ and $28 \%$, respectively. In years 2012-2017, both the sown area and crops more than doubled (Table 1) making Poland one of the major European herb producer [Buchwald 2015].

In the herbal industry, as in other enterprises associated with the processing of plant raw material, significant amounts of wastes are generated. Only in the north-eastern Poland, two largest suppliers of herb products "Herbapol Białystok S.A." and "Dary Natury" generate $\sim 30$ tonnes per year [Obidziński 2010] and $\sim 50$ tonnes per year [darynatury.pl] of wastes, respectively. The wastes from herb industry contain a lot of organic substances that can be successfully used for other purposes. Due to their bactericidal, immunostimulating, antioxidant and sedative effects, herbal wastes are mainly used as fodder additives [Hanczakowska 2007].

The wastes generated during packaging are difficult to utilize because of their variety and properties. They are often sold cheaply; sometimes, the price covers only the transportation costs [Obidziński 2013] while they are a potential source of energy. The research on lemon balm waste revealed that this herb waste is characterized with the energy value similar to other lignocelluloses raw materials. Therefore, lemon balm (Melissa officinalis L.) waste used as an additive in the production of granules or briquettes can become a fully-fledged, cheap fuel in biomass heating plants [Obidziński 2010].

The energy accumulated in this plant raw material can also be used to produce biogas. Due to the relatively small amounts of waste generated in the herbal industry, it should not be assumed that the herb wastes will become an intrinsic substrate used for the biogas production. However, if another utilization method is not possible, the herb waste could become a potential raw material in co-digestion defined as an anaerobic treatment of a mixture of different substrates, which aims at improving the efficiency of anaerobic digestion [Alvarez et al. 2010].

Every co-substrate may increase or decrease the biogas production; therefore, before using specific waste as an addition to a stable installation its properties and specific biogas and methane yield should be checked. Many plants produce secondary metabolites, such as saponins and tannins, which have antimicrobial properties [Wallace 2004], thus may inhibit the anaerobic digestion process. Therefore, the purpose of the study was to assess the suitability of waste of two herbal plants, lemon balm and alder buckthorn, for biogas production.

\section{MATERIAL AND METHODS}

The waste of lemon balm (Melissa officinalis L.) and alder buckthorn (Frangula alnus Mill.) formed during the packaging of the raw material were obtained from the plant processing herbs. The methane potential test (BMP) was performed using air-dried material. Inoculum was obtained from the agricultural biogas plant treating maize silage $(80 \%)$ with the addition of swine manure (ca. 10\%) and by-products of agro-food processing (ca. 10\%). The inoculum was pre-incubated in $38 \pm 1^{\circ} \mathrm{C}$ in water bath to lower the endogenous methane production. In the substrates and inoculum the following parameters were

Table 1. Area, yield and crops of herbs and spices in Poland in years 2012-2017

\begin{tabular}{|l|c|c|c|c|c|c|}
\hline \multicolumn{1}{|c|}{ Year } & 2012 & 2013 & 2014 & 2015 & 2016 & 2017 \\
\hline Sown area [ha] & 14544 & 13091 & 12168 & 17115 & 20885 & 30564 \\
\hline Yield [dt ha- ${ }^{-1}$ & 14.3 & 14.2 & 14.9 & 12.4 & 16.4 & 14.4 \\
\hline Crop [dt] & 208521 & 186212 & 181042 & 212468 & 343544 & 441248 \\
\hline
\end{tabular}

Source: Based on Statistics Poland (GUS). 
determined: total solids (TS), volatile solids (VS), total Kjeldahl nitrogen (TKN), total organic carbon (TOC), total phosphorus (P), total potassium $(\mathrm{K})$ and $\mathrm{pH}$. TS and VS were determined according to standard methods (APHA 1998), $\mathrm{pH}$ was measured with HQD40 meter (Hach, USA). TOC was determined with a TOC-L analyser equipped with SSM-5000A Solid Sample Combustion Unit (Shimadzu, Japan), TKN was determined with a Vapodest 50s analyser (Gerhardt, Germany). After nitric acid/hydrogen peroxide microwave digestion in ETHOS One (Milestone s.r.l., Italy) the content of $\mathrm{P}$ was measured with ammonium metavanadate method using a UV-1800 spectrophotometer (Shimadzu, Japan) and K content with a flame photometer (BWB Technologies, England). The analyses were performed in triplicates.

The BMP was conducted in eudiometer sets made of 1-liter bottle (reaction vessel) and 600 $\mathrm{ml}$ tube. The $0.1 \mathrm{~N} \mathrm{Na}_{2} \mathrm{SO}_{4}$ solution was used as a confining solution. To each bottle, $350 \mathrm{ml}$ of inoculum was added, followed by the appropriate amount of the substrate at a $\mathrm{VS}_{\text {inoculum }} / \mathrm{VS}_{\text {substrate }}$ ratio of 2. In order to correct the methane potential resulting from the endogenous respiration of inoculum, the bottles with inoculum only were incubated as controls. All the bottles were filled with distilled water to reach TS equal to 5 . Before inserting the tube into the bottle, the bottle headspace was flushed with nitrogen gas for ca. $2 \mathrm{~min}$. to ensure the anaerobic conditions. The BMP test was performed at $38 \pm 1^{\circ} \mathrm{C}$ in water bath. Each day, the contents of the bottles were mixed manually. The biogas yield was monitored on a daily basis with the liquid displacement method. The biogas composition was analyzed with portable biogas analyser DP-28BIO (NANOSENS, Poland). At the beginning of the experiment, the measurements were taken every day, while in the later period, with lower biogas production, the composition of biogas was checked 2-3 times a week. The temperature and air pressure in the laboratory were determined with a weather station. The BMP tests were terminated after 36 days, when the daily methane production was less than $1 \%$ of the accumulated volume of methane [Holliger et al. 2016]. The BMP tests were conducted in triplicate, and the results were expressed as mean value \pm standard deviation.

In order to calculate the SMY substrate, the methane yield of the inoculum was subtracted from that of the inoculum and substrate mixture. The SMY is expressed as the volume of dry methane gas under standard conditions (273.15 K and $1013 \mathrm{hPa}$ ) per mass of volatile solids (VS) added, with the unit $\mathrm{NL}_{\mathrm{CH} 4} \mathrm{~kg}_{\mathrm{VS}}{ }^{-1}$.

Significant differences between the studied wastes were determined by t-test using Statistica 13.1 (StatSoft) software.

\section{RESULTS AND DISCUSSION}

\section{Inoculum and substrates}

The inoculum had the properties typical for digestate from agricultural biogas plant. The substrates had similar TS and TOC content, but differed in terms of other properties, affecting the intensity of biogas production. The TS of both substrates was much higher than this parameter of the substrates typically used in the biogas production. The TS of silage from main and secondary crops, catch crops, annual grass and legume mixtures and perennial crops which can be used as substrate in biogas production is, on average, equal to $28.9 \%$ [Herrmann et al. 2016], the TS of animal slurry varies from 3 to $12 \%$ [Scarlat et al. 2018] and the average TS of animal manure is equal to $21.37 \%$ [Maćkowiak, Żebrowski 2000]. High TS value implicates both studied substrates as good co-substrates for raw material with low TS value. Alder buckthorn waste was characterized with VS similar to crop silages which is, on average, equal to $92.2 \%$ [Herrmann et al. 2016] while the VS of lemon balm is similar to the VS of solid manure which is in a range of $70-80 \%$ [Scarlat et al. 2018]. Higher TKN content $(\mathrm{p}<0.001)$ characterized the alder buckthorn bark (Table 2). This substrate was also characterized by a narrower $\mathrm{C} / \mathrm{N}$ ratio $(\mathrm{p}<0.05)$, which according to Fricke et al. [2007] should be in the range of 20 to 30 . However, both substrates were characterized with wide $\mathrm{C} / \mathrm{N}$ ratio, indicating the need of adding a substrate with higher $\mathrm{N}$ content. The $\mathrm{C} / \mathrm{N}$ ratio was almost double comparing to maize silage, the $\mathrm{C} / \mathrm{N}$ ratio of which ranges from 35 to 45 [Veluchamy et al. 2019]. In both substrates, the TOC content was much higher than in maize silage (149.57 $\mathrm{g} \mathrm{kg}^{-1}$, unpublished data) while the TKN content was similar in the case of lemon balm and higher in the case of alder buckthorn. Both herb wastes were characterized with much higher TKN content comparing to cattle slurry (3.187 $\mathrm{g} \mathrm{kg}^{-1}$ ) [Wysocka-Czubaszek et al. 2018] and animal manure $\left(4.8 \mathrm{~g} \mathrm{~kg}^{-1}\right)$ [Maćkowiak, 
Żebrowski 2000]. Much higher P and K contents ( $p<0.001$ ) were observed in lemon balm waste and these values exceeded the $\mathrm{P}$ and $\mathrm{K}$ content in cattle slurry $\left(\mathrm{P}-0.03 \mathrm{~g} \mathrm{~kg}^{-1} ; \mathrm{K}-6.81 \mathrm{~g} \mathrm{~kg}^{-1}\right)$ [Wysocka-Czubaszek et al. 2018] and in animal manure $\left(\mathrm{P}-1.35 \mathrm{~g} \mathrm{~kg}^{-1} ; \mathrm{K}-5.56 \mathrm{~g} \mathrm{~kg}^{-1}\right)$ [Maćkowiak, Żebrowski 2000].

\section{Daily biogas and methane production}

Different trends of daily biogas and methane production from lemon balm and alder buckthorn wastes were observed. The main differences between these two substrates were number and time of peaks in daily production. In the case of lemon balm, in the first three days a decrease in biogas production was observed, which in the following days began to increase, reaching its maximum on

Table 2. Chemical properties of inoculum and studied wastes

\begin{tabular}{|c|c|c|c|}
\hline Parameter & Inoculum & Lemon balm & Alder buckthorn \\
\hline $\mathrm{pH}$ & $\begin{array}{c}7.28 \\
\pm 0.11\end{array}$ & n.a. & n.a. \\
\hline $\begin{array}{l}\text { TS } \\
{[\%]}\end{array}$ & $\begin{array}{c}4.78 \\
\pm 0.06\end{array}$ & $\begin{array}{r}91.19 \\
\pm 1.81\end{array}$ & $\begin{array}{r}90.81 \\
\pm 1.19\end{array}$ \\
\hline $\begin{array}{c}\text { VS } \\
{[\% \text { of TS] }}\end{array}$ & $\begin{array}{r}73.98 \\
\pm 0.29\end{array}$ & $\begin{array}{l}71.03 \\
\pm 2.97\end{array}$ & $\begin{array}{l}93.31 \\
\pm 2.69\end{array}$ \\
\hline $\begin{array}{c}\text { TOC } \\
{\left[\mathrm{g} \mathrm{kg}^{-1}\right]}\end{array}$ & $\begin{array}{r}395.2 \\
\pm 41.9\end{array}$ & $\begin{array}{r}420.9 \\
\pm 29.1\end{array}$ & $\begin{array}{l}472.0 \\
\pm 28.0\end{array}$ \\
\hline $\begin{array}{c}\text { TKN } \\
{\left[\mathrm{g} \mathrm{kg}^{-1}\right]}\end{array}$ & $\begin{array}{r}71.0 \\
\pm 2.3\end{array}$ & $\begin{array}{l}6.81 \\
\pm 0.2\end{array}$ & $\begin{array}{l}9.67 \\
\pm 0.2\end{array}$ \\
\hline $\mathrm{C} / \mathrm{N}$ & $\begin{array}{r}5.56 \\
\pm 0.4\end{array}$ & $\begin{array}{l}61.81 \\
\pm 2.19\end{array}$ & $\begin{array}{l}48.81 \\
\pm 3.19 \\
\end{array}$ \\
\hline $\begin{array}{c}\mathrm{P} \\
{\left[\mathrm{g} \mathrm{kg}^{-1}\right]}\end{array}$ & $\begin{array}{r}10.6 \\
\pm 3.0 \\
\end{array}$ & $\begin{array}{c}2.5 \\
\pm 0.1 \\
\end{array}$ & $\begin{array}{c}0.8 \\
\pm 0.1 \\
\end{array}$ \\
\hline $\begin{array}{c}\mathrm{K} \\
{\left[\mathrm{g} \mathrm{kg}^{-1}\right]}\end{array}$ & $\begin{array}{r}70.9 \\
\pm 1.1\end{array}$ & $\begin{array}{r}15.4 \\
\pm 1.1\end{array}$ & $\begin{array}{c}2.3 \\
\pm 0.2\end{array}$ \\
\hline
\end{tabular}

$\mathrm{pH}$ - reaction; TS - total solids; VS - volatile solids; TOC - total organic carbon; TKN - total Kjeldahl nitrogen content; $\mathrm{P}$ - total phosphorus content; $\mathrm{K}$ total potassium content; n.a. - not analysed; C, N, P, K concentration reported on fresh mass basis. the 7th day (Figure 1). After relative stabilization, from the 11th day, biogas production started to fall to the 20th day and from this moment until the end of experiment it remained at level of $0.02 \mathrm{NL} \mathrm{d}^{-1}$. The biogas production from alder buckthorn had a completely different character. After a slight increase on the 2nd day, a long drop began until 8th day. In the following days, a slight upward trend was observed, followed by a rapid increase in the intensity of this process on days $12-16$. The maximum daily biogas production from alder buckthorn lasted for 5 days and was similar to the maximum daily production of lemon balm. This maximum production was followed by a sharp decline to 0.03 $\mathrm{NL} \mathrm{d}^{-1}$, which - with slight fluctuations - persisted until the end of the experiment.

The methane content of $65 \%$ was reached on the 14th day in the biogas samples produced from lemon balm. The relatively constant value (66-68\%) was reached at the 16th day (Figure 2) and was observed until the end of the experiment. Until the 13th day of the experiment, in the samples of biogas produced from alder buckthorn, the methane content did not exceed $10 \%$. The content of $60 \%$ was achieved on the 23rd day of experiment and until the end of BMP test, the methane concentration in biogas did not exceed $64 \%$. Both substrates were characterized with higher methane content than the biogas produced from energy crops equal on average to $56.2 \%$ [Herrmann et al. 2016].

The daily methane production from anaerobic digestion of lemon balm and alder buckthorn followed the pattern of the biogas production (Figure 3). For lemon balm, the daily production increased from the first day of experiment and the highest daily methane production was observed on the 11th day. In the next 10 days, the production decreased and until the end of experiment, it was less than $0.02 \mathrm{NL} \mathrm{d}^{-1}$. The daily methane production rate from alder buckthorn showed the

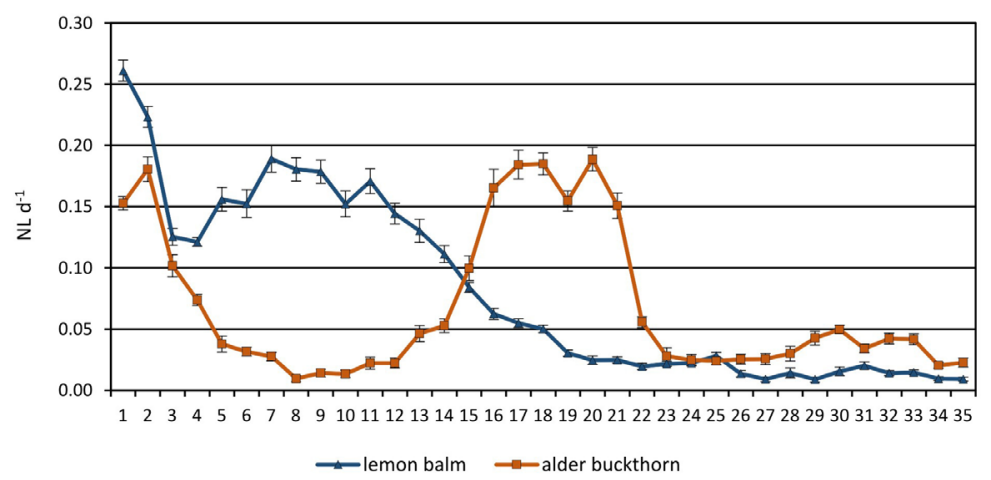

Figure 1. Daily biogas production (mean value \pm standard deviation, where absent, bars fall within symbols) 


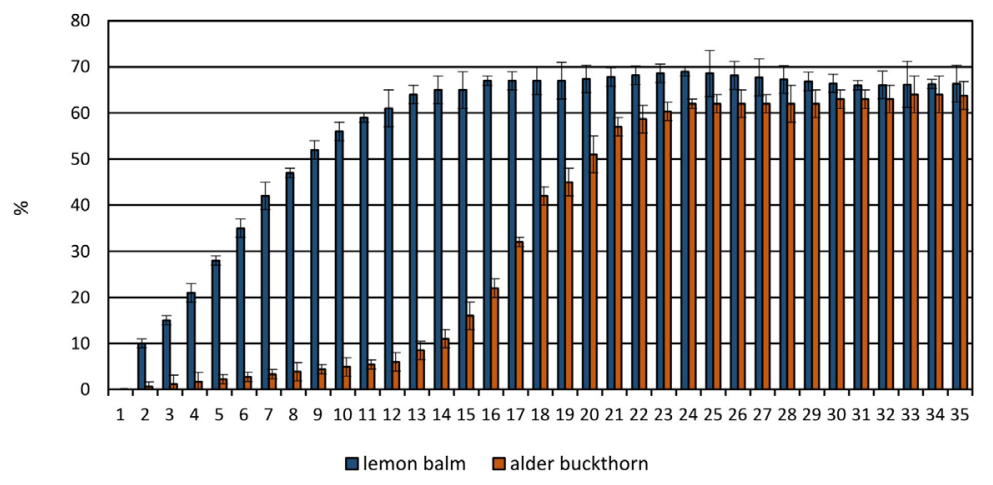

Figure 2. Changes in the methane content in the following days of the experiment (mean value \pm standard deviation)

opposite pattern. In the first two weeks, the daily methane production was close to 0 and rapidly increased in next 6 days, reaching the maximum value on the 20th day of experiment. This peak was followed by a rapid decrease to the values ca. $0.02-0.03 \mathrm{NL} \mathrm{d}^{-1}$ and stayed on this level until the end of experiment (Figure 3).

\section{Cumulative biogas and methane production}

A different pattern in the daily biogas production for both studied substrates did not clearly affect the total amount of biogas produced during the entire experiment (Figure 4). Within 35 days of experiment, lemon balm and alder buckthorn produced $461 \pm 23$ and $386 \pm 33 \mathrm{NL} \mathrm{kg}_{\mathrm{VS}}{ }^{-1}$ of biogas, respectively.

However, the opposite patterns of daily methane production and its content clearly affected the differences in SMY of both tested substrates $(\mathrm{p}<0.05)$ (Figure 5). The SMY of lemon balm was equal to $197 \pm 14 \mathrm{NL} \mathrm{kg}_{\mathrm{Vs}}{ }^{-1}$, while the SMY of alder buckthorn amounted to $122 \pm 11 \mathrm{NL} \mathrm{kg}_{\mathrm{vs}}{ }^{-1}$.

The observed differences may be caused by a variation in the chemical properties of the studied wastes. In the case of lemon balm, the methane bacteria had access to a nutrient-rich substrate.
According to Desideri et al. [2010], the lemon balm leaves contain much more potassium $(\mathrm{K})$, magnesium $(\mathrm{Mg})$, phosphorus $(\mathrm{P})$ and sulfur $(\mathrm{S})$ in comparison to the alder buckthorn bark. The chemical composition of wastes used as substrate for BMP tests in the presented study confirmed the results of Desideri et al. [2010] in the case of $\mathrm{P}$ and $\mathrm{K}$. Lower SMY of alder buckthorn is in a good agreement with García-González et al. [2008] who studied the impact of the addition of various medicinal plants on the fermentation of ruminants. The addition of alder buckthorn caused a reduction of methane production while the addition of lemon balm did not have the adverse effect on the digestion process.

On a fresh weight basis, both lemon balm and alder buckthorn have higher SBY compared to maize silage [Myczko et al. 2011], the most popular substrate used in biogas installations (Table 3). However, expressing the results based on the VS content, only the lemon balm is in the average range for maize, which is mainly related to its higher content of TS in comparison with alder buckthorn. According to the feedstock categorization based on SBY, both substrates belong to the category of feedstock producing low

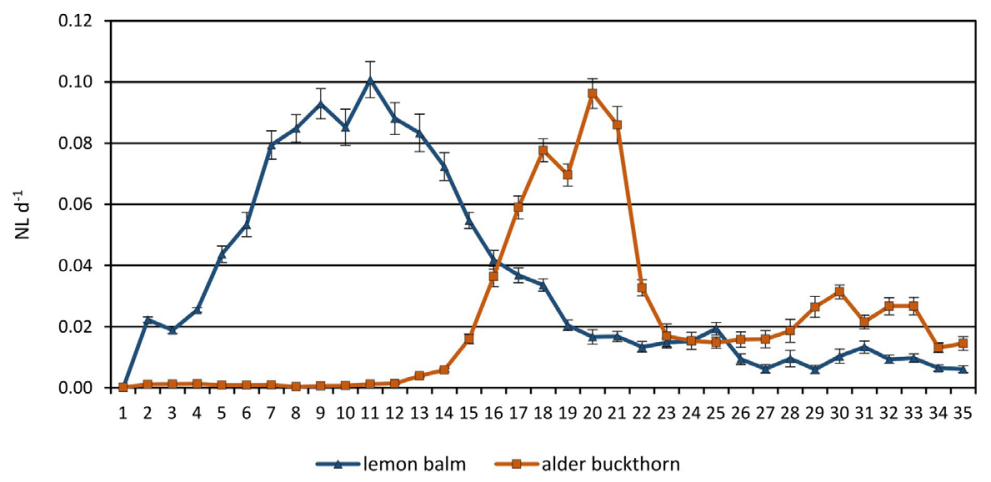

Figure 3. Daily methane production (mean value \pm standard deviation, where absent, bars fall within symbols) 


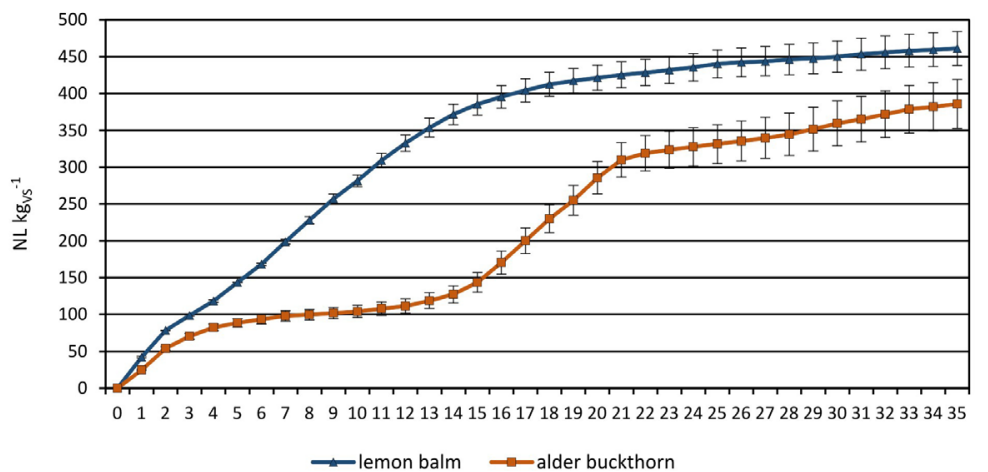

Figure 4. Biogas yield from lemon balm and alder buckthorn (mean value \pm standard deviation, where absent, bars fall within symbols)

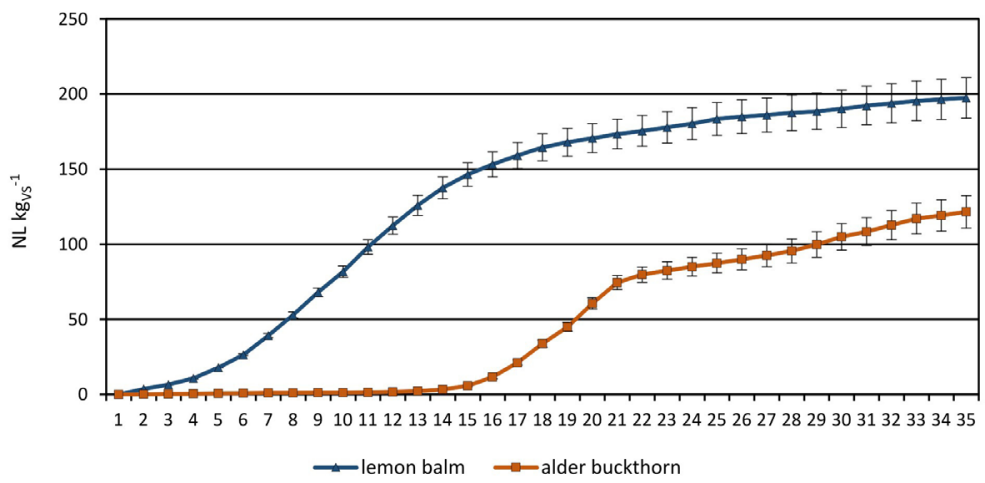

Figure 5. Methane yield from lemon balm and alder buckthorn (mean value \pm standard deviation, where absent, bars fall within symbols)

yield of biogas which is typical for lignocellulose, cattle and pig manure [Langeveld, Petersons 2018]. The methane yield was higher from lemon balm and was similar to the SMY of pig slurry (201 NL $\mathrm{kg}_{\mathrm{vS}}{ }^{-1}$ ) and lignocellulose feedstock such as pre-treated bagasse $\left(177 \mathrm{NL} \mathrm{kg}_{\mathrm{Vs}}{ }^{-1}\right)$, forest residue (214 $\left.\mathrm{NL} \mathrm{kg}_{\mathrm{VS}}{ }^{-1}\right)$ and pre-treated coffee pulp (174 NL kg ${ }_{\mathrm{vs}}^{-1}$ ) [Langeveld, Petersons 2018]. The SMY of alder buckthorn was similar to the SMY obtained from bagasse $\left(122 \mathrm{NL} \mathrm{kg}_{\mathrm{VS}}{ }^{-1}\right)$ and coffee pulp (131 NL kg ${ }_{\mathrm{vS}}{ }^{-1}$ ) [Langeveld, Petersons 2018].

The wastes from the herbal industry were also the subject of research by Lewicki et al. [2013]. The results obtained in this paper are higher in relation to the fresh mass, but much lower in terms of the TS of substrate.

\section{CONCLUSIONS}

1. The analyzed wastes of the herbal industry can be useful co-substrates in the biogas production. Although the quantity of these wastes is low, they are cheap and therefore their codigestion may decrease the costs of biogas production.

2. The lemon balm waste provided a higher biogas potential yield, which is comparable with the potential of maize silage. The higher content of readily available nutrients caused that the anaerobic digestion process started almost immediately and remained at an elevated level for a longer time compared to alder buckthorn.

3. The differences in the kinetics of the anaerobic digestion process observed in the tested wastes

Table 3. Cumulative biogas and methane production

\begin{tabular}{|l|c|c|c|c|c|c|}
\hline \multirow{2}{*}{\multicolumn{1}{|c|}{ Specification }} & \multicolumn{3}{|c|}{ Biogas } & \multicolumn{3}{c|}{ Methane } \\
\cline { 2 - 7 } & $\mathrm{NL} \mathrm{kg}_{\mathrm{Vs}}{ }^{-1}$ & $\mathrm{NL} \mathrm{kg}_{\mathrm{TS}}{ }^{-1}$ & $\mathrm{NL} \mathrm{kg}_{\mathrm{FM}}{ }^{-1}$ & $\mathrm{NL} \mathrm{kg}_{\mathrm{Vs}}{ }^{-1}$ & $\mathrm{NL} \mathrm{kg}_{\mathrm{TS}}{ }^{-1}$ & $\mathrm{NL} \mathrm{kg}_{\mathrm{FM}}{ }^{-1}$ \\
\hline Lemon balm & $461.00 \pm 23$ & $327.45 \pm 16$ & $298.60 \pm 14$ & $197.00 \pm 14$ & $139.93 \pm 10$ & $127.60 \pm 9$ \\
\hline Alder buckthorn & $386.00 \pm 33$ & $360.18 \pm 30$ & $327.08 \pm 27$ & $122.00 \pm 11$ & $113.84 \pm 10$ & $103.38 \pm 9$ \\
\hline $\begin{array}{l}\text { Maize silage (Myczko } \\
\text { et al., 2011) }\end{array}$ & $450-700$ & & $170-200$ & & & \\
\hline
\end{tabular}

TS - total solids; VS - volatile solids; FM- fresh matter. 
may have a beneficial effect on the relatively high biogas production throughout the retention period in the digester.

\section{Acknowledgments}

This work was financially supported by Ministry of Science and Higher Education as a part of the project $\mathrm{S} / \mathrm{WBiIS} / 01 / 17$.

\section{REFERENCES}

1. Álvarez J.A., Otero L., Lema J.M. 2010. A methodology for optimising feed composition for anaerobic co-digestion of agro-industrial wastes. Bioresour. Technol., 101, 1153-1158.

2. Angelidaki I., Ellegard L. 2003. Codigestion of manure and organic wastes in centralized biogas plants. Appl. Biochem. Biotechnol., 109, 95-105.

3. Bogdanovic A., Tadic V., Arsic I., Milovanovic S., Petrovic S., Skala D. 2016. Supercritical and high preassure subcritical fluid extraction from Lemon balm (Melissa officinalis L., Lamiaceae). J. of Supercritical Fluids, 107, 234-242.

4. Buchwald W. 2015. Kierunki rozwoju produkcji zielarskiej. Online at: http://kongres.cdr.gov.pl/images/P3_4_Buchwald.pdf, accessed 02.06.2019.

5. Czubaszek R., Wysocka-Czubaszek A. 2018. Emissions of carbon dioxide and methane from fields fertilized with digestate from an agricultural biogas plant. International Agrophysics, 32, 29-37.

6. Darynatury.pl. Online at: https://darynatury.pl/Podstrony/Zagospodarowanie-odpadow, 12. accessed 02.06.2019.

7. Desideri D., Meli M. A., Roselli C. 2010. Determination of essential and non-essential elements in some medicinal plants by polarised $\mathrm{X}$ ray fluorescence spectrometer (EDPXRF). Microchemical Journal, 95, 174-180.

8. Fricke K. 2007. Operating problems in anaerobic digestion plants resulting from nitrogen in MSW. Waste Management, 27, 30-43.

9. García-González R., López S., Fernández, M., Bodas R., González J.S. 2008. Screening the activity of plants and spices for decreasing ruminal methane production in vitro. Animal Feed Science and Technology, 147, 36-52.

10. Hanczakowska E. 2007. Herbs and herbal preparations in pig feeding [In Polish]. Wiadomości Zootechniczne, R. XLV, 3, 19-23.

11. Herrmann C., Idler C., Heiermann M. 2016. Biogas crops grown in energy crop rotations: Linking chemical composition and methane production characteristics. Bioresource Technology, 206, 23-35.

12. Holliger C. et al. 2016. Towards a standardization of biomethane potential tests. Water Sci. Technol., 74(11), 2515-2522.
13. Langeveld J.W.A., Peterson E.C. 2018 Feedstock for biogas production: biogas and electricity generation potentials. [In:] Tabatabaei M., Ghanavati H. (eds.) Biogas. Fundamentals, process and operation. Biofuel and Biorafinery Technologies, 6, 35-50.

14. Lewicki A., Pilarski K., Janczak D., Czekała W., Rodríguez Carmona P. C., Cieślik M., Witaszek K. 2013. The biogas production from herbs and waste from herbal industry. Journal of Research and Applications in Agricultural Engineering, 58 (1), 114-117.

15. Maćkowiak C., Żebrowski J. 2000. Chemical composition of farmyard manure in Poland [In Polish]. Nawozy i Nawożenie, 4(5), 119-130.

16. Myczko A., Myczko R., Kołodziejczyk T., Golimowska R., Lenarczyk J., Janas Z., KliberA., Karłowski J., Dolska M. 2011. Construction and operation of agricultural biogas plants [In Polish]. Wydawnictwo ITP, Warszawa-Poznań.

17. Newerli-Guz J. 2016. Growing herbal plants in Poland [In Polish]. Roczniki Naukowe Stowarzyszenia Ekonomistów Rolnictwa i Agrobiznesu, tom XVIII 18, z. 3, 268-274.

18. Obidziński S. 2010. Evaluation of energy properties of lemon balm waste [In Polish]. Zeszyty Problemowe Postępów Nauk Rolniczych, z. 546, 253-262.

19. Obidziński S. 2013. Characteristics of water activity and geometric parameters of lemon balm waste in the aspect of their use as a feed additive [In Polish]. Acta Agrophysica, 20(1), 113-124.

20. Panyadee S., Petiraksakul A., Phalakornkule C. 2013. Biogas production from co-digestion of Phyllanthus emblica residues and food waste. Energy for Sustainable Development, 17, 515-520.

21. Scarlat N., Dellemend J.-F., Fahl F. 2018. Biogas: Developments and perspectives in Europe. Renewable Energy, 129, 457-472.

22. Statistics Poland 2018, Crop production in 2017, GUS, Warszawa.

23. Teleszewski T. J., Żukowski M. 2018. Analysis of heat loss of a biogas anaerobic digester in weather conditions in Poland. Journal of Ecological Engineering, 19 (4), 242-250.

24. Wallace R.J. 2004. Antimicrobial properties of plant secondary metabolites. Proc. of Nutr. Soc., 63, 621-629.

25. Veluchamy C., Gilroyed B.H., Kalamdahad A.S. 2019. Process performance and biogas production optimizing of mesophilic plug flow anaerobic digestion of corn silage. Fuel, 253, 1097-1103.

26. Wysocka-Czubaszek A. 2019. Dynamics of nitrogen transformations in the soil fertilized with digestate from agricultural biogas plant. Journal of Ecological Engineering, 20 (1), 108-117.

27. Wysocka-Czubaszek A., Czubaszek R., Roj-Rojewski S., Banaszuk P. 2018. Comparative study on effects of digestate and cattle slurry application on $\mathrm{N}$ dynamics in fertilized soil. Proc. Conf. Engineering for Rural Development, 1804-1809. 